\title{
Establishment of a Mouse Model of Premature Ovarian Failure Using Consecutive Superovulation
}

\author{
Xiaowei Nie $^{\mathrm{a}}$ Youjin Dai ${ }^{\mathrm{b}}$ Yuan Zheng ${ }^{\mathrm{b}} \quad$ Dan Bao $^{\mathrm{b}} \quad$ Qin Chen \\ Yuan Yin ${ }^{b}$ Heling Fu ${ }^{b}$ Daorong Hou \\ aDepartment of Reproductive Medicine, Affiliated Hospital of Nanjing University of Traditional Chinese \\ Medicine, Nanjing, 'Key Laboratory of the Model Animal Research, Animal Core Facility of Nanjing \\ Medical University, Nanjing Medical University, Nanjing, China
}

\section{Key Words}

Ovulation • Oxidative stress $\cdot$ Apoptosis $・$ Premature ovarian failure $\bullet$ Ovary aging

\begin{abstract}
Background/Aims: This study investigated the effect of consecutive superovulation on the ovaries and established a premature ovarian failure (POF) model in mice. Methods: The mouse POF model was induced by 5-15 consecutive superovulation treatments with pregnant mare serum gonadotropin (PMSG), human chorionic gonadotropin (HCG) and prostaglandin F2 $\alpha$ (PGF2 $\alpha$ ). Normal adult mice were compared with mice displaying natural ovarian aging. The following serum biochemical parameters were measured: including follicle-stimulating hormone $(F S H)$, luteinizing hormone $(\mathrm{LH})$, progesterone $(\mathrm{P})$, estradiol $(\mathrm{E} 2)$, inhibin $\mathrm{B}(\mathrm{INH} B)$, malondialdehyde (MDA), total superoxide dismutase (SOD) and glutathione peroxidase (GSH$\mathrm{Px}$ ) levels. Follicles were counted using $\mathrm{H} \& \mathrm{E}$ staining. Levels of 8-hydroxyguanosine (8-OhdG), 4-hydroxynonenal (4-HNE), nitrotyrosine (NTY), anti-Mullerian hormone (AMH) and CDKN2A/ p16 (p16) were detected using immunohistochemical staining. Reactive oxygen species (ROS) levels were measured using dihydroethidium (DHE) staining. Cell apoptosis was detected using an in situ TUNEL fluorescence staining assay. Levels of proteins involved in ROS-related pathways and the p16 protein were detected using Western blotting. Sod1, Sod2 and Sod3 mRNA levels were detected using quantitative polymerase chain reaction (Q-PCR). Oocyte quality was evaluated using in vitro fertilization (IVF) and zygote culture. Results: Consecutive superovulation groups presented lower P, E2, SOD, GSH-Px and INH B levels, significantly higher FSH, LH, MDA and ROS levels, and significantly fewer primordial follicles compared with the control group. Consecutive superovulation groups presented significantly increased levels of Sod2, 8-OhdG, 4-HNE, NTY, significantly increased levels of the SIRT1 and FOXO1 proteins, significantly increased levels of the senescence-associated protein p16, as well as decreased $\mathrm{AMH}$, Sod1 and Sod3 levels and increased granulosa cell apoptosis compared with the control group. Conclusion: Consecutive superovulation significantly decreased ovarian
\end{abstract}

$X .-w$. Nie and Y.-j. Dai contributed equally to this work. 


\section{Cellular Physiology Cell Physiol Biochem 2018;51:2341-2358 \\ and Biochemistry \begin{tabular}{l|l} 
DOI: 10.1159/000495895 & $\begin{array}{l}\text { O } 2018 \text { The Author(s). Published by S. Karger AG, Basel } \\
\text { www.karger.com/cpb }\end{array}$
\end{tabular} \\ Nie et al.: Establishment of a Mouse Model of Premature Ovarian Failure}

function and oocyte quality and increased oxidative stress and apoptosis in the ovary via a mechanism involving the $\mathrm{p} 16$ and SIRT1/FOXO1 signaling pathways. These findings suggest that consecutive superovulation may be used to establish a mouse model of ovarian aging.

(C) 2018 The Author(s)

Published by S. Karger AG, Basel

\section{Introduction}

Premature ovarian failure (POF), also referred to as premature ovarian insufficiency (POI), is a condition that affects $1 \%$ of women in the general population and causes amenorrhea and hypergonadotropic hypoestrogenism before the age of 40 years [1]. Previously, POF was believed to be irreversible; however, it was later shown that in POF, residual ovarian function may remain despite the presence of elevated gonadotrophins [1]. An incomplete understanding of the pathogenesis of POF is a major hurdle for the development of effective therapeutic options for this disease [2]. Therefore, elucidation of the mechanism for POF development is critical for the clinical treatment of this disease. However, there are restrictions in performing thorough studies in humans.

The estrous cycle of female mice is similar to that of humans, although the estrous cycle of mice is shorter than that of humans [3]. Currently, mouse models of female reproductive aging are divided into two categories: genetic mutation animal models, such as the follitropin receptor knockout animal model $[4,5]$ and the dioxin/aryl hydrocarbon receptor knockout animal model [6, 7]; and poison damage models, such as the 4-vinylcyclohexene diepoxide-induced female reproductive aging model $[8,9]$ and the D-galactose-induced female reproductive aging model [10-12]. Although these animal models show an increase in follicular consumption or even depletion, the resulting estrous cycle disorders, decreased sex hormone secretion and decrease in or loss of fertility may indicate one or more pathological states and thus do not simulate the real pathophysiological condition of ovarian aging [8, 13]. An animal model that simulates the pathophysiological state of the complex process of ovarian aging is needed to elucidate the mechanism.

The mechanism of ovulation in the ovaries is similar to inflammatory responses, and this process increases the synthesis of prostaglandins [14], histamine [15], and bradykinin [16]. Peroxides and related metabolites play an important role in the rupture of the follicular wall, a prerequisite of ovulation [17-19]. Female mammals are born with a limited number of primordial follicles. Each follicle contains an oocyte and granulocyte layer that stall at the first meiosis stage [20]. During the entire reproductive period of a female mammal, the ovulation cycle occurs approximately 400 to 500 times. Oxidative stress is a necessary prerequisite for luteinization $[20,21]$, which also disrupts the microenvironment of egg cells and granule cells [22] and reduces the vitality of oocytes and embryos [23,24]. According to studies by Van Blerkom et al., a decrease in the antioxidant levels in the follicular and oviduct microenvironment result in oocyte deterioration [24]. Ovarian aging has been confirmed to lead to reproductive cycle disorders, oocyte aneuploidy, and a disruption of blastocyst maturation $[25,26]$. Oxidative stress plays a crucial role in ovulation, and oxidative damage gradually accumulates in oocytes and associated cells during repeated ovulation [27]. Therefore, the exposure of oocytes and related cells to oxidative stress during the process of repeated ovulation represents an important cause of ovarian aging.

For rodents, it is very difficult to use pregnant mare serum gonadotropin (PMSG) and human chorionic gonadotropin (HCG) to induce superovulation repeatedly since the progesterone (P) secreted by the corpus luteum inhibits the secretion of the pituitary gonadotropin [20]. Therefore, the removal of the corpus luteum is particularly important for initiating the next round of the ovulation cycle. The injection of PMSG and HCG will prolong the luteal phase in rodents, and the subsequent injection of prostaglandin F2 $\alpha$ (PGF2 $\alpha$ ) will induce dissolution of the luteum $[20,21]$. In this study, we used continuous intraperitoneal injection of PMSG, HCG and PGF2 $\alpha$ to induce consecutive superovulation, investigated the effect of consecutive superovulation on mouse ovary, and established a stable, physiologic POF mouse model. 


\section{Cellular Physiology Cell Physiol Biochem 2018;51:2341-2358 \begin{tabular}{l|l|l} 
and Biochemistry Published onlIne: 8 December 2018 & $\begin{array}{l}\text { (c) } 2018 \text { The Author(s). Published by S. Karger AG, Basel } \\
\text { www.karger.com/cpb }\end{array}$ \\
\hline
\end{tabular}}

Nie et al.: Establishment of a Mouse Model of Premature Ovarian Failure

\section{Materials and Methods}

\section{Chemicals}

All chemicals and reagents were purchased from Sigma Chemical Co. (St. Louis, MO, USA) unless otherwise indicated.

\section{Animal care and use}

One hundred fifty C57BL/6 female mice aged 7-8 weeks and thirty C57BL/6 female mice aged 44 weeks were used. Animals were obtained from the Animal Core Facility of Nanjing Medical University, Nanjing, China, and housed in a $12 \mathrm{~h}$ dark/light cycle animal facility with controlled temperature $\left(20 \sim 25^{\circ} \mathrm{C}\right)$ and humidity (40\% 70\%). Food and water were provided ad libitum throughout the study. All animal experiments were approved by the Institutional Animal Care and Use Committee (IACUC) of Nanjing Medical University, Jiangsu, China, and methods were carried out in accordance with the approved guidelines.

\section{Experimental design}

All mice were allowed to acclimatize for 1 week. C57BL/6 female mice aged 7-8 weeks were then randomly divided into 5 groups of 30 mice each: the control group (control), consecutive superovulation 5 times group [CS(5)], consecutive superovulation 10 times group [CS(10)], consecutive superovulation 15 times group [CS(15)] and consecutive superovulation 15 times group after an intraperitoneal injection with the oxidation inhibitor superoxide dismutase (SOD) (500 U/kg, S9697, Sigma, St. Louis, MO, USA) [CS(15)+SOD]. For induction of ovulation, the mice were intraperitoneally administered 5 IU of HCG (Ningbo Second Hormone Factory, Ningbo, China) $48 \mathrm{~h}$ after administration of 5 IU of PMSG (Ningbo Second Hormone Factory, Ningbo, China). Nineteen hours after HCG administration, 25 IU of PGF2 $\alpha$ (Hangzhou Animal Medicine Factory, Hangzhou, China) was administered intraperitoneally [28]. Three injections comprised one complete ovulation cycle, and the next cycle began $12 \mathrm{~h}$ later. Mice from the CS(5) group sequentially underwent 5 ovulation cycles; mice from the CS(10) group underwent 10 ovulation cycles; mice from the $\mathrm{CS}(15)$ group underwent 15 ovulation cycles; and mice in the control group received an equal volume of saline injection intraperitoneally at the same time. Thirty aged C57BL/ 6 female mice ( 40 weeks old) served as the natural ovarian aging (NOA) group. Twelve hours after the last drug administration, mice were sacrificed under general anesthesia using intraperitoneal injection of pentobarbital sodium $(150 \mathrm{mg} /$ $\mathrm{kg}$ ). Blood was collected through cardiac puncture; the ovaries were excised immediately and stored at $-80^{\circ} \mathrm{C}$ until the biochemical analysis or fixed with $4 \%$ paraformaldehyde for histological studies.

\section{Sample preparation and biochemical assays}

The ovaries and bodies of all mice were weighed, and blood samples were collected in diestrus, allowed to clot at room temperature and centrifuged at $3000 \mathrm{rpm}$ for $10 \mathrm{~min}$ to harvest serum. Serum biochemical parameters, including the serum follicle-stimulating hormone (FSH), luteinizing hormone (LH), progesterone (P), estradiol (E2) and inhibin B (INH B) levels, were measured spectrophotometrically (Eon, BioTeK, Vermont, UT, USA) using the following commercially available ELISA kits: FSH (KA2330), LH (KA2332), INH B (KA1683) (Novus Biologicals, Littleton, USA), E2 (582251), and P (582601) (Cayman Chemicals, Ann Arbor, MI, USA).

The ovaries were washed in ice-cold saline and homogenized in $0.1 \mathrm{M}$ Tris-HCl buffer ( $\mathrm{pH}$ 7.4). The homogenates were centrifuged at 10, $000 \mathrm{~g}$ for $15 \mathrm{~min}$, and the supernatants were centrifuged at 100, 000 $\mathrm{g}$ for $1 \mathrm{~h}$. The resulting supernatant (cytosolic fraction) was used to determine the enzymatic activity and lipid peroxidation levels. The biochemical parameters of the ovaries, including malondialdehyde (MDA) level and total superoxide dismutase (SOD) and glutathione peroxidase (GSH-Px) activities, were measured spectrophotometrically using commercially available kits for MDA (A003-1), SOD (A001-1) and GSH-Px (A003) (Jiancheng Bioengineering Institute, Nanjing, China).

\section{Follicle counting}

The right ovaries were embedded in paraffin after $12 \mathrm{~h}$ fixation in $4 \%$ paraformaldehyde. They were serially sectioned $(6 \mu \mathrm{m})$, mounted on glass slides, and stained with H\&E. All ovarian follicles were counted according to a previous study $[29,30]$. In brief, every fifth ovary section was observed under a microscope. Only those with a visible oocyte nucleus were included to avoid repeated counts of the same 


\section{Cellular Physiology Cell Physiol Biochem 2018;51:2341-2358

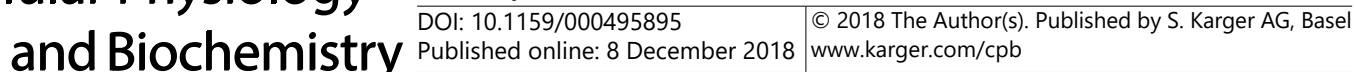 \\ Nie et al.: Establishment of a Mouse Model of Premature Ovarian Failure}

follicle. The number of primordial follicles in all the serial sections of an ovary was counted. The following follicle classification was utilized [31,32]: type 1: primordial follicle, one layer of flattened granulosa cells surrounding the oocyte; type 2: primary follicle, one to two complete layers of cuboidal granulosa cells; type 3: secondary follicle, an oocyte surrounded by more than one layer of cuboidal granulosa cells with no visible antrum; type 4: antral follicle, an oocyte surrounded by multiple layers of cuboidal granulosa cells and containing one or more antral spaces, possibly with a cumulus oophorus and thecal layer and type 5: atretic follicle, a follicle that enters a degenerative process without ovulation. The atretic follicles were included in the denominator when calculating the total follicles.

\section{Immunohistochemical staining}

For immunohistochemical analysis, the paraffin sections were dewaxed first, and then, heat-mediated antigen retrieval was performed by microwaving sections for $20 \mathrm{~min}$ in $10 \mathrm{mM}$ sodium citrate, $\mathrm{pH}$ 6.0. Sections were cooled for $15 \mathrm{~min}$, followed by a brief wash in deionized water, and rinsed twice in PBS. Sections were incubated for $30 \mathrm{~min}$ in $5 \%$ goat serum in DPBS containing $0.1 \%$ Tween and $0.5 \%$ BSA. Sections were incubated overnight at $4{ }^{\circ} \mathrm{C}$ with the appropriate dilutions of primary antibodies against 8-hydroxyguanosine (8-OhdG, ab26842), 4-hydroxynonenal (4-HNE, ab48506), anti-Mullerian hormone (AMH, ab24542), and CDKN2A/p16 (p16, ab189034) from Abcam Biotechnology and nitrotyrosine (NTY, sc-71007) from Millipore Biotechnology. The secondary antibody from the Dako REAL EnVisio Detection System (K5007, DAKO, Denmark) was used to detect the staining. Then, the specimens were counterstained with hematoxylin for $1 \mathrm{~min}$. All sections were incubated under the same conditions with the same concentration of antibodies at the same time.

\section{DHE staining}

The redox-sensitive, cell-permeable fluorophore DHE (1890512, Invitrogen, USA) was used to evaluate in situ production of superoxide. DHE is oxidized by superoxide to a novel product that binds to DNA, enhancing intracellular fluorescence [33]. Unlike lucigenin, DHE does not undergo redox cycling to form superoxide [34]. DHE (10 mM) was applied to unfixed frozen sections, incubated in a light-protected humidified chamber at $37^{\circ} \mathrm{C}$ for $30 \mathrm{~min}$, washed with PBS, and mounted with fluorescent mounting medium (DAKO). Fluorescence images were obtained at excitation and emission wavelengths of 540/25 nm and $605 / 55 \mathrm{~nm}$, respectively. The fluorescence intensity values from five different fields of view were quantified using ImageJ software (http://rsbweb.nih.gov/ij/).

\section{In situ TUNEL fluorescence staining assay}

The terminal deoxynucleotidyl transferase (TdT)-mediated deoxyuridine triphosphate (dUTP) nick end labeling (TUNEL) assay was performed according to the manufacturer's instructions (11684817910, Roche, Switzerland). The ovarian tissues were fixed in $4 \%$ paraformaldehyde overnight, dehydrated, embedded in paraffin, cut at 4- $\mu \mathrm{m}$-thick sections, and placed on a numbered polylysine-coated glass slide. Deparaffinized tissue sections were incubated with proteinase $\mathrm{K}(20 \mathrm{mg} / \mathrm{ml})$ in a humidified chamber for $15 \mathrm{~min}$, and endogenous peroxidase activity was inhibited by treatment with $3 \mathrm{H}_{2} \mathrm{O}_{2}$ for $10 \mathrm{~min}$. Sections were then incubated with TdT labeling buffer at $37^{\circ} \mathrm{C}$ for $1 \mathrm{~h}$ in a moist chamber. They were counterstained with DAPI. TUNEL-positive cells were stained green; nuclei were stained with DAPI to observe the nature of the TUNEL-positive cells.

\section{Western blotting}

Western blotting analysis was performed according to previously described methods [12]. Briefly, 50 $\mu \mathrm{g}$ of total lysate obtained from ovarian tissue was subjected to $15 \%$ polyacrylamide gel electrophoresis and then transferred to a cellulose acetate membrane. The membranes were blocked with $1 \times$ casein solution for approximately $4 \mathrm{~h}$ and then incubated with mouse monoclonal anti- p16 (ab189034), anti-SIRT1 (ab110304) and anti-FOXO1 (ab52857) antibodies obtained from Abcam Biotechnology and anti-GAPDH (H-12) (sc-166574) antibody obtained from Santa Cruz Biotechnology in blocking buffer for $2 \mathrm{~h}$ at room temperature. The membranes were washed 3 times with TBST and then incubated with a goat anti-mouse IgG HRP-conjugated secondary antibody (sc-2005, Santa Cruz Biotechnology). Then, the membranes were washed 3 times in TBST, and the blots were imaged using the ChemiDoc XRS+ Molecular Imager (Bio-Rad) with Pierce ECL Western Blotting Substrate (32209, Thermo Scientific) and analyzed using image analysis 


\section{Cellular Physiology Cell Physiol Biochem 2018;51:2341-2358 and Biochemistry Published $\begin{aligned} & \text { DOI: 10.1159/000495895 } \\ & \text { (c) } 2018 \text { The Author(s). Published by S. Karger AG, Basel } \\ & \text { www.karger.com/cpb }\end{aligned}$ \\ Nie et al.: Establishment of a Mouse Model of Premature Ovarian Failure}

software (ImageJ 1.42). The housekeeping protein GAPDH was used as the internal reference. The Western blotting quantification was corrected to GAPDH expression prior to normalization.

$Q-P C R$

Total mRNA was extracted from ovaries using TRIzol reagent (B5704-1, Takara, Dalian, China) according to the manufacturer's instructions, followed by treatment with DNase I (2212, Takara, Dalian, China) according to the manufacturer's protocol. RNA quality and quantity were determined using a spectrophotometer (NanoDrop 2000c, Thermo Scientific, USA). The cDNA templates were then synthesized immediately using Prime Script ${ }^{\mathrm{TM}} \mathrm{RT}$ reagent Kit (RR037A, Takara, Dalian, China) according to the manufacturer's instructions. Q-PCR was performed using Light Cycler PCR QC Kit (Roche, Switzerland) and the 7300 Real-Time PCR System (LC96, Roche, Switzerland). The primer sequences used herein are as follows: Sod1 (NM_011434.2) forward: GCTGTACCAGTGCAGGACCTCAT, reverse: CTCTCCTGAGAGTGAGATCACACGA; Sod2 (NM_017051) forward: ATGGTGGGGGACATATT, reverse: GAACCTTGGACTCCCACAGA; Sod3 (NM_011435.3) forward: CCTGCTGCTCGCTCACATAACAG, reverse: TGGACTCCCCTGGATTTGACATG; and $\beta$-actin (NM_007393.3), forward: GTGACGTTGACATCCGTAAAGA, reverse: GTAACAGTCCGCCTAGAAGCAC. The housekeeping gene Gapdh was used as an internal reference. GraphPad Prism 5 software was used to analyze the data and produce graphs.

In vitro fertilization (IVF) and zygote culture

Oocyte quality was evaluated after consecutive superovulation and SOD injection to further illuminate the role of oxidative stress in the ovary during consecutive superovulation. The mice were administered $5 \mathrm{IU}$ of HCG $48 \mathrm{~h}$ after the administration of 5 IU of PMSG. Fifteen hours after HCG administration, the mice were euthanized. Then, their ovaries were removed, ruptured using scissors, and placed in T6 media containing $15 \mathrm{mg} / \mathrm{ml} \mathrm{BSA}$, and incubated at $37.5^{\circ} \mathrm{C}$ in a $5 \% \mathrm{CO}_{2}$ atmosphere for at least for 15 minutes. The number of oocytes from each mouse was recorded. Sperm were released from ruptured epididymis of C57BL/6 mice and were incubated at for least $30 \mathrm{~min}$ to induce capacitation. Oocytes obtained from each group were subjected to IVF by transferring the cells into $100 \mu \mathrm{l}$ of IVF medium droplets and $2 \times 10^{6} \mathrm{sperm} /$ $\mathrm{ml}$ were added to the droplets. After $6 \mathrm{~h}$, each IVF droplet containing oocytes and sperm was evaluated under an inverted microscope and the percentage of embryos with male and female nuclei (2PNs) was recorded as the fertilization rate. Afterwards, the newly produced $2 \mathrm{PNs}$ were washed, transferred to T6 medium containing $4 \mathrm{mg} / \mathrm{ml} \mathrm{BSA}$, and incubated $\left(37.5^{\circ} \mathrm{C}\right.$ in $\left.5 \% \mathrm{CO}_{2}\right)$ for 96 hours. Embryos at the 2-cell and blastocyst stages were counted 24 and 96 hours after IVF [35].

\section{Statistical analysis}

All statistical analyses were performed using SPSS v.16. All results are shown as the mean \pm standard deviation $(\mathrm{M} \pm \mathrm{SD}$ ). All statistical comparisons were performed using one-way ANOVA followed by Duncan's multiple range post hoc analysis. A $P$ value $<0.05$ was considered significant.

\section{Results}

Effect of consecutive superovulation on the HPG axis and INH B level

The NOA group had significantly increased serum FSH and LH levels $(P<0.01)$ and significantly decreased E2, $P$ and INH B levels $(P<0.01)$ compared to the control group (Fig. 1A-D). More than 10 consecutive superovulatory treatments significantly increased the serum FSH and LH levels $(P<0.05$, Fig. 1A, B) and decreased the serum E2, P and INH B levels $(P<0.01$, Fig. 1C, D, E).

\section{Effect of consecutive superovulation on follicle number}

Follicle counting was performed after H\&E staining (Fig. 2A). The follicle classification was based on the characteristics proposed by Hirshfield \& Midgley [36]. Follicle counting showed that more than 10 consecutive superovulatory treatments reduced the numbers of primordial follicles, primary follicles and secondary follicles compared to those in the control group $(P<0.05$ or $P<0.01$, Fig. $2 \mathrm{~B})$ and increased the numbers of antral follicles, 


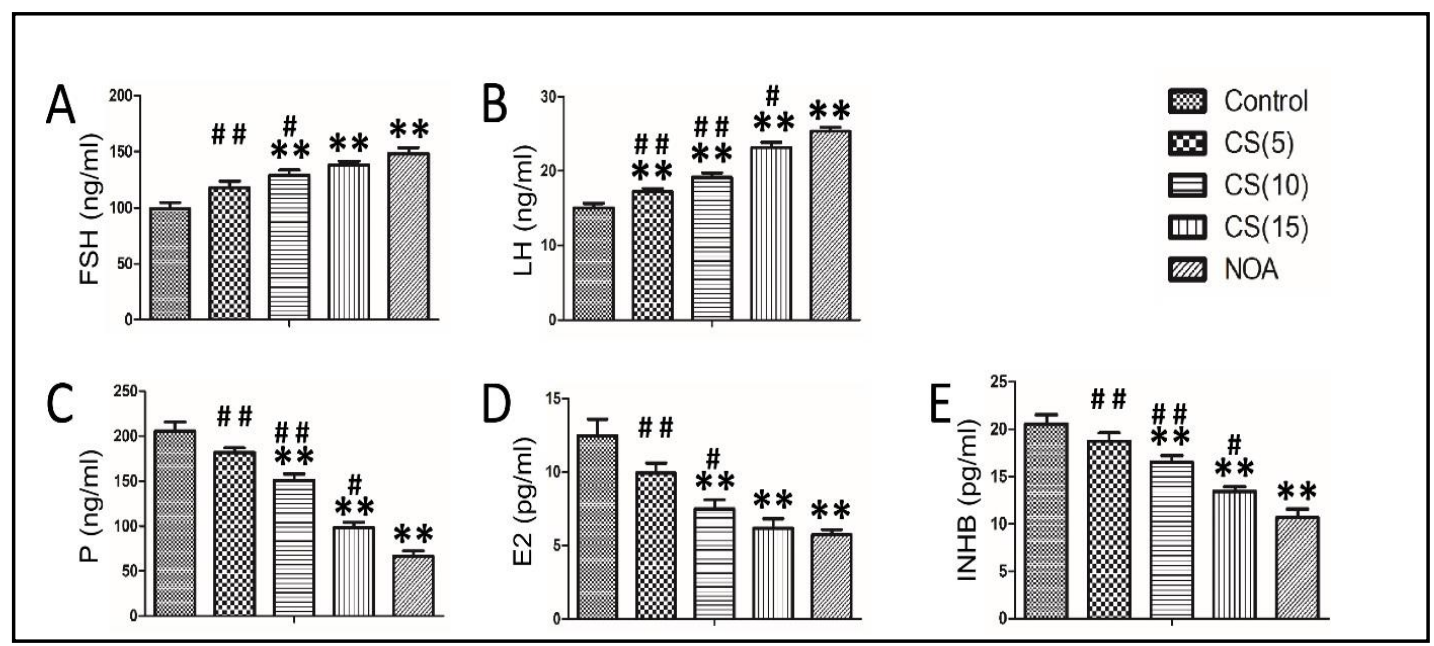

Fig. 1. Effect of consecutive superovulation on the HPG axis and INH B level. The serum FSH (A), LH (B), P (C), E2 (D) and INH B (E) levels were tested in five groups, and AMH mRNA expression in the ovarian tissues (E) was also tested. Ten mice per group were examined. All data are presented as means \pm SD. Statistical significance: ${ }^{*} \mathrm{P}<0.05$ and ${ }^{* *} \mathrm{P}<0.01$ vs the control group, ${ }^{*} \mathrm{P}<0.05$ and ${ }^{\# *} \mathrm{P}<0.01$ vs the NOA group.

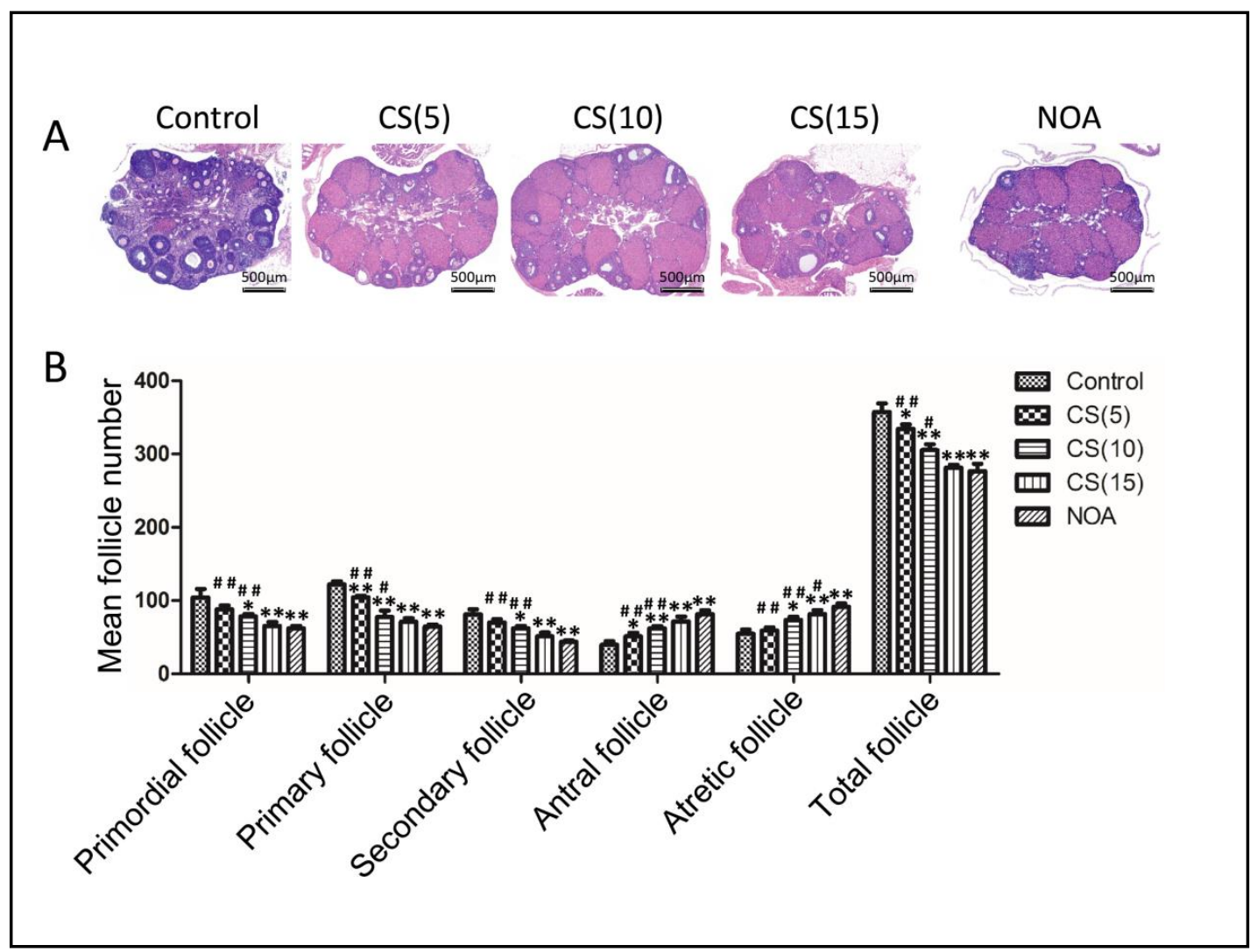

Fig. 2. Effect of consecutive superovulation on follicle number. (A) Follicles were observed after H\&E staining. The follicle classification was based on the characteristics proposed by Hirshfield and Midgley. (B) The numbers of these follicles at different developmental stages of maturation are summarized $(n=8$ per group). All data are presented as means \pm SD. Statistical significance: ${ }^{*} \mathrm{P}<0.05$ and ${ }^{* *} \mathrm{P}<0.01$ vs the control group, ${ }^{\#} \mathrm{P}<0.05$ and ${ }^{\# \#} \mathrm{P}<0.01$ vs the NOA group. 


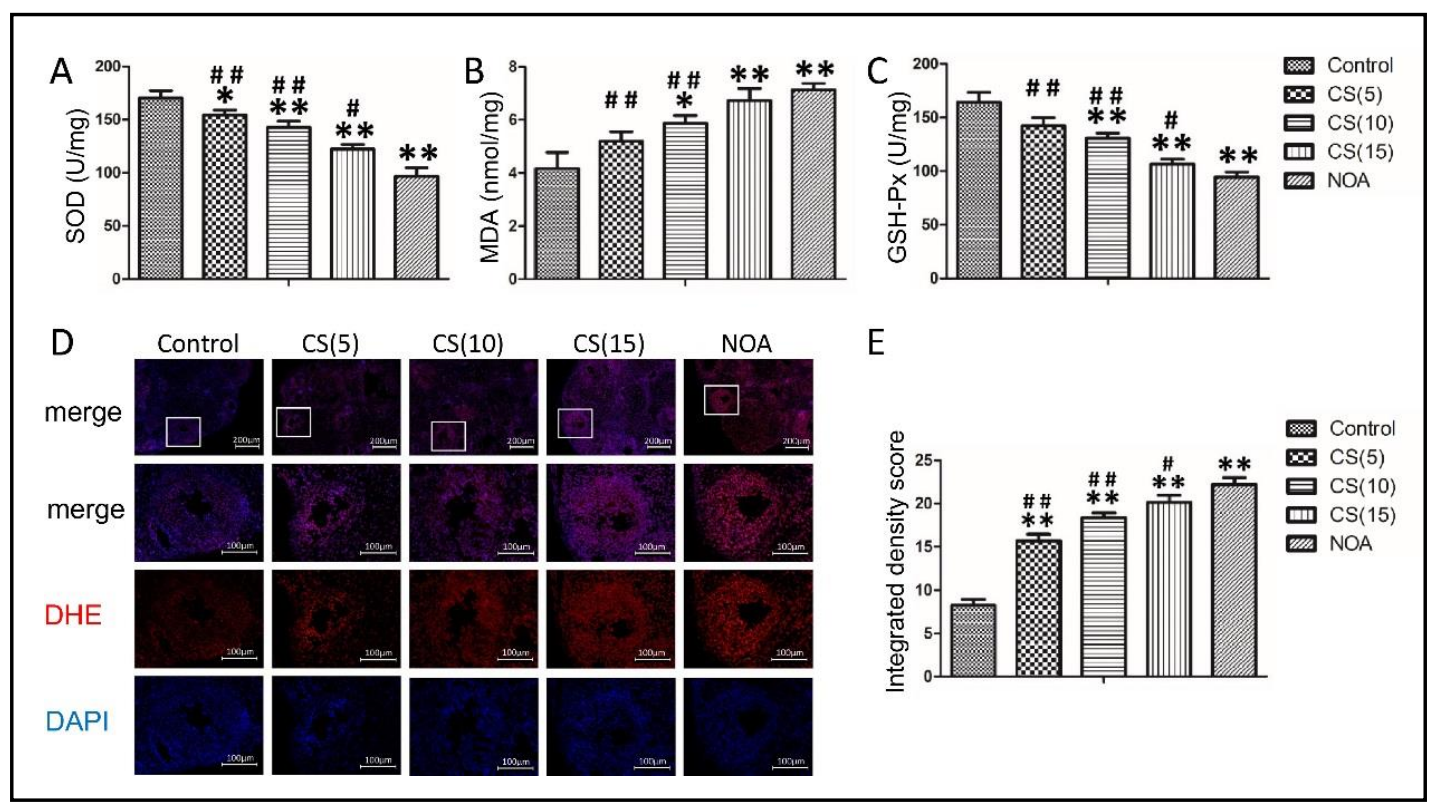

Fig. 3. Effects of consecutive superovulation on oxidative stress. The total SOD (A) and GSH-Px (B) enzyme activities and the MDA level (C) were measured in the ovarian tissues ( $n=8$ animals per group). (D) Representative images of ovarian tissue sections from mice ( $n=8$ animals per group) stained with DHE and visualized using confocal microscopy. (E) The intensity of staining was quantified using ImageJ. Data are presented as means \pm SD. Statistical significance: ${ }^{*} \mathrm{P}<0.01$ and ${ }^{* *} \mathrm{P}<0.01$ vs the control group; ${ }^{*} \mathrm{P}<0.05$ and ${ }^{\# \#} \mathrm{P}<0.01$ vs the NOA group.

atretic follicles and the total follicles compared to those in the control group $(P<0.05$ or $P$ $<0.01$, Fig. 2B). Except for atretic follicles, there were no significant differences in follicle numbers between the CS (15) group and NOA group.

\section{Effect of consecutive superovulation on the follicle number}

Follicles were counted in H\&E-stained sections (Fig. 2A). Follicles were classified based on the characteristics proposed by Hirshfield \& Midgley. More than 10 consecutive superovulation treatments led to reduced numbers of primordial follicles, primary follicles and secondary follicles $(P<0.05$ or $P<0.01$, Fig. 2B) and increased numbers of antral follicles, atretic follicles and total follicles $(P<0.05$ or $P<0.01$, Fig. $2 \mathrm{~B})$ compared to the control group. With the exception of atretic follicles, a significant difference in follicle numbers was not observed between the CS (15) group and NOA group.

\section{Effects of consecutive superovulation on oxidative stress}

A significant reduction in total SOD and GSH-Px enzyme activities was detected in the ovarian tissues from the NOA group compared with the tissues from the control group $(P$ $<0.01$, Fig. $3 A$ and $B$ ), and a significantly higher MDA level was observed in the NOA group compared with the control group $(P<0.01$, Fig. $3 C)$. More than 10 consecutive superovulatory treatments resulted in substantially lower SOD and GSH-Px enzyme activities and higher MDA levels compared with the control group $(P<0.05$ or $P<0.01$, Fig. $3 \mathrm{~A}-\mathrm{C})$.

We visualized the intracellular generation of the ROS moiety $\mathrm{O}^{2-}$ with the fluorescent probe DHE to assess the effects of consecutive superovulation on ROS production (Fig. 3D). In this assay, the superoxide anion oxidizes DHE to a novel product that binds DNA, leading to increased fluorescence [33]. Confocal microscopy showed that ovary sections from NOA mice exhibited a widespread and marked increase in DHE fluorescence compared with the controls $(P<0.01$, Fig. 3E), and more than 5 consecutive superovulatory treatments also induced a significant increase in ROS fluorescence intensity compared with the controls $(P$ $<0.01$, Fig. 3E).

\section{KARGER}




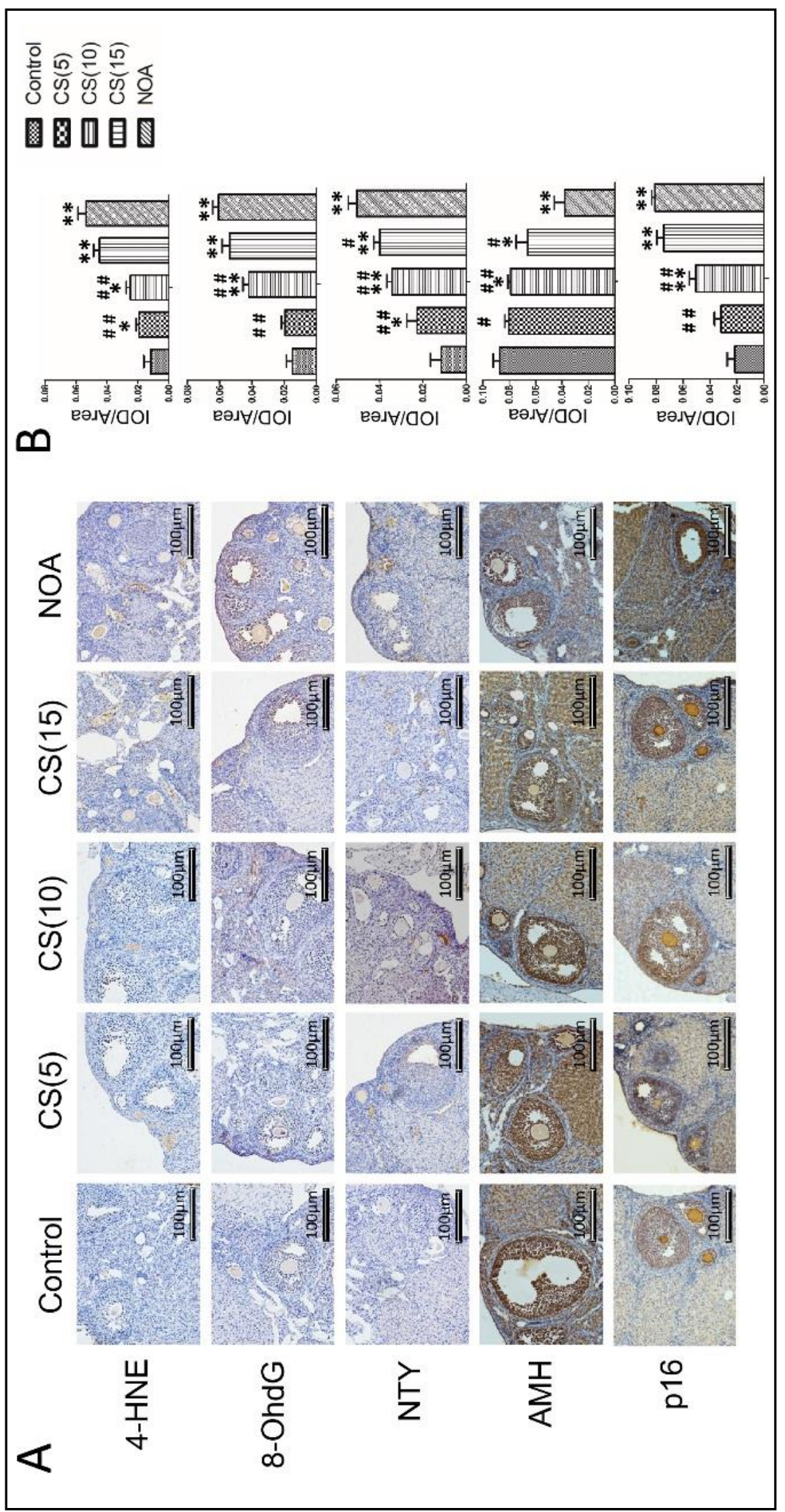

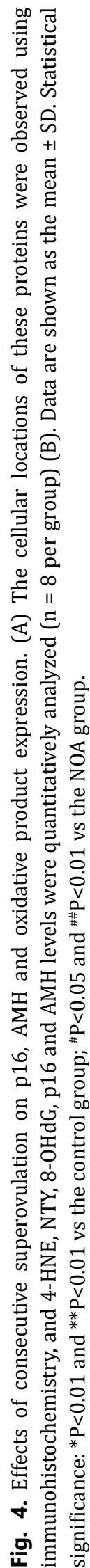



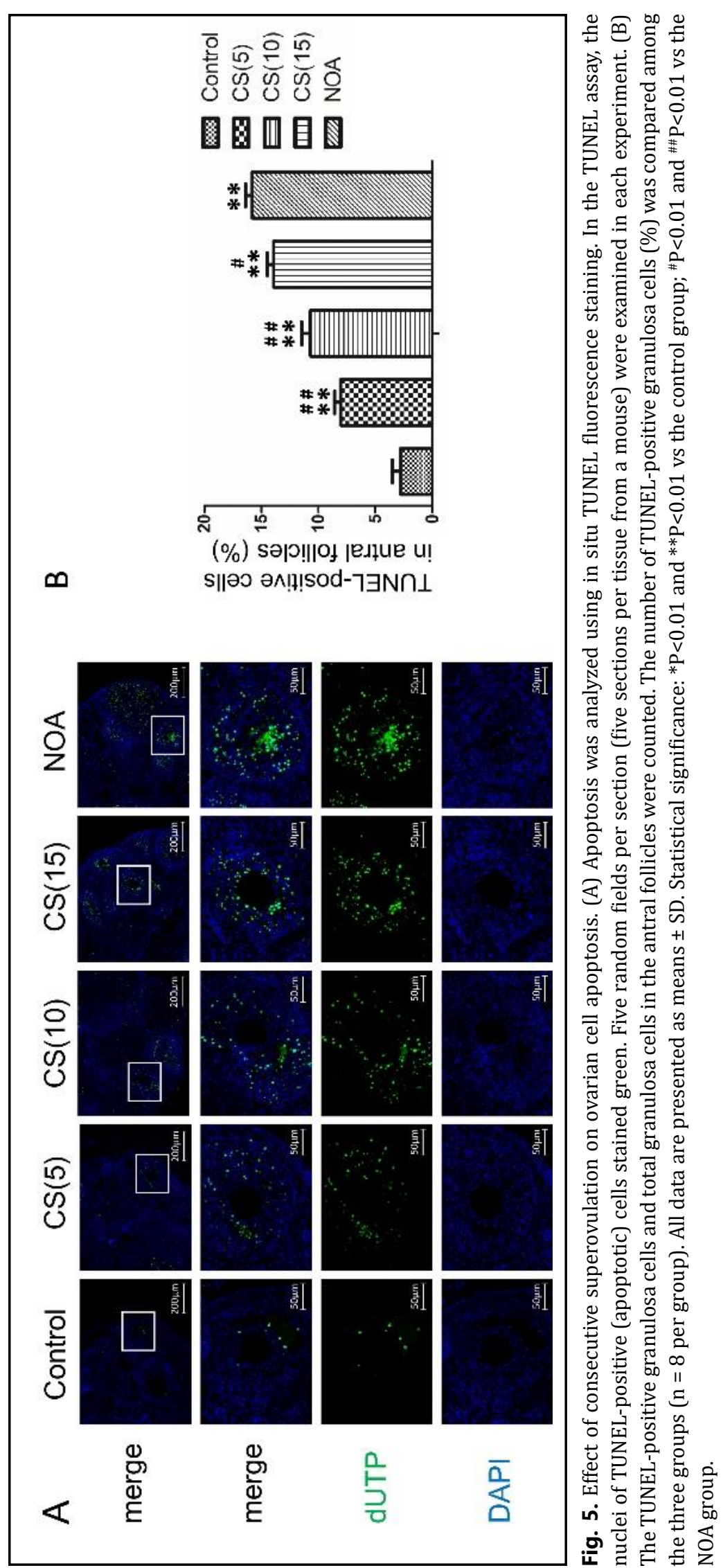


\section{Cellular Physiology Cell Physiol Biochem 2018;51:2341-2358 \begin{tabular}{l|l|l} 
and Biochemistry Published online: 8 December 2018 & $\begin{array}{l}\text { (c) } 2018 \text { The Author(s). Published by S. Karger AG, Basel } \\
\text { www.karger.com/cpb }\end{array}$ \\
\hline
\end{tabular}

\section{Effects of consecutive superovulation on $p 16, A M H$ and oxidative product expression}

The cellular locations of the 4-HNE, NTY, 8-OHdG and p16 proteins were examined using immunohistochemistry (Fig. 4A). The 4-HNE, NTY and 8-OHdG proteins were primarily located in the ovarian interstitial cells, and low levels were observed in follicular granulosa cells. The 4-HNE, 8-OhdG and NTY protein levels were significantly higher in the NOA group than the control group $(P<0.01$, Fig. 4B), whereas the expression levels were partially and significantly decreased in the consecutive superovulation groups $(P<0.05$ and $P<0.01$, respectively).

The AMH protein was primarily located in follicular granulosa cells, while the senescence-associated p16 protein was predominantly located in follicular granulosa cells and oocytes (Fig. 4A), and relatively lower AMH and p16 levels were observed in the ovarian interstitial cells. Consistent with the 4-HNE, 8-OhdG and NTY protein levels, consecutive superovulation induced a significant increase in p16 protein expression and decrease in AMH protein expression in a cycle number-dependent manner $(P<0.05$ or $P<0.01$, Fig. 4B).

\section{Effect of consecutive superovulation on ovarian cell apoptosis}

In the TUNEL assay, the nuclei of the TUNEL-positive (apoptotic) cells stained green (Fig. 5A). The number of apoptotic granulosa cells in the antral follicles was assessed in the five groups. More TUNEL-positive cells were detected in the NOA group than the control group $(P<0.01$, Fig. 6B). Consecutive superovulation significantly increased the number of TUNEL-positive cells compared with the number in the control group, suggesting a positive effect on induction of ovarian cell apoptosis $(P<0.05$ or $P<0.01)$.

Effect of consecutive superovulation on 16 protein expression and ROS-related pathways in the ovary

We investigated the potential mechanisms involved in the effects of consecutive superovulation on ovarian aging. The levels of oxidative stress signaling pathway-associated markers were assessed using Western blotting (Fig. 6). The p16 level was markedly higher in the NOA group than the control group $(P<0.01)$ and was significantly higher in the consecutive superovulation groups in a cycle number-dependent manner than the control group $(P<0.05$ or $P<0.01)$. The SIRT1 and FOX01 protein levels were significantly lower in the NOA group than the control group $(P<0.01)$, whereas the SIRT1 and FOXO1 protein levels were significantly lower in the consecutive superovulation groups than the control group $(P<0.05$ or $P<0.01)$. There was no significant difference in STIR1 expression between the CS(15) group and the NOA group.

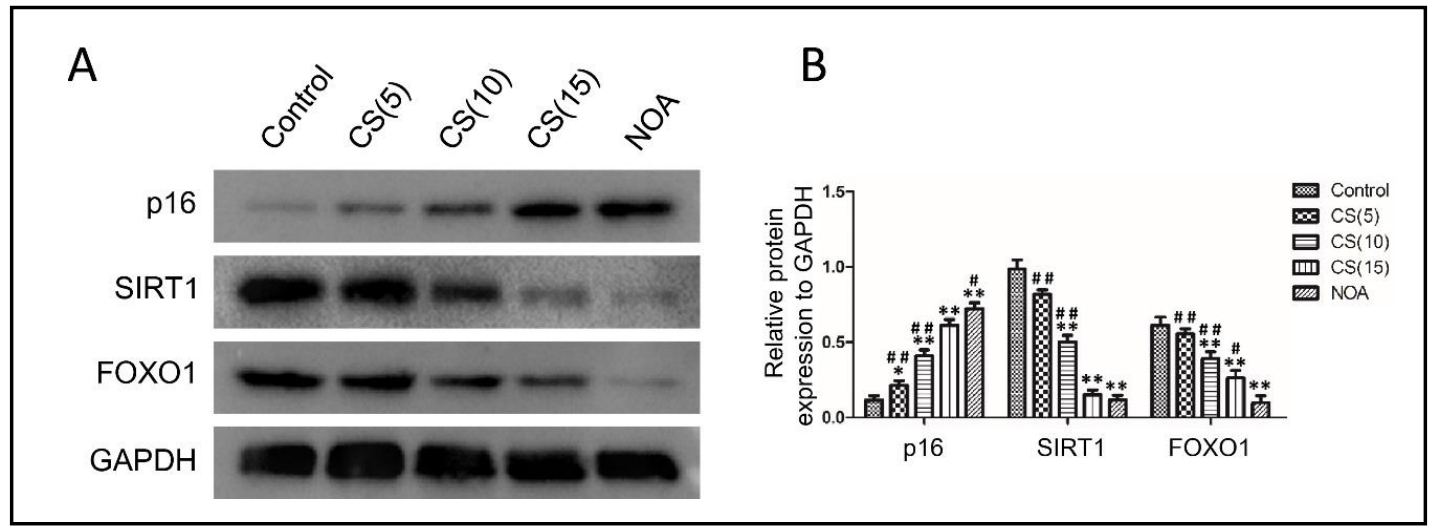

Fig. 6. Effect of consecutive superovulation on the expression of the p16 protein and proteins involved in ROS-related pathways in the ovary. (A) The p16, SIRT1 and FOX01 protein levels in ovarian tissues were detected using Western blotting. (B) The protein expression levels were quantitatively analyzed $(n=6$ per group). Data are presented as means \pm SD. Statistical significance: ${ }^{*} \mathrm{P}<0.01$ and ${ }^{* *} \mathrm{P}<0.01$ vs the control group; ${ }^{\mathrm{P}}<0.05$ and ${ }^{\# \#} \mathrm{P}<0.01$ vs the NOA group. 


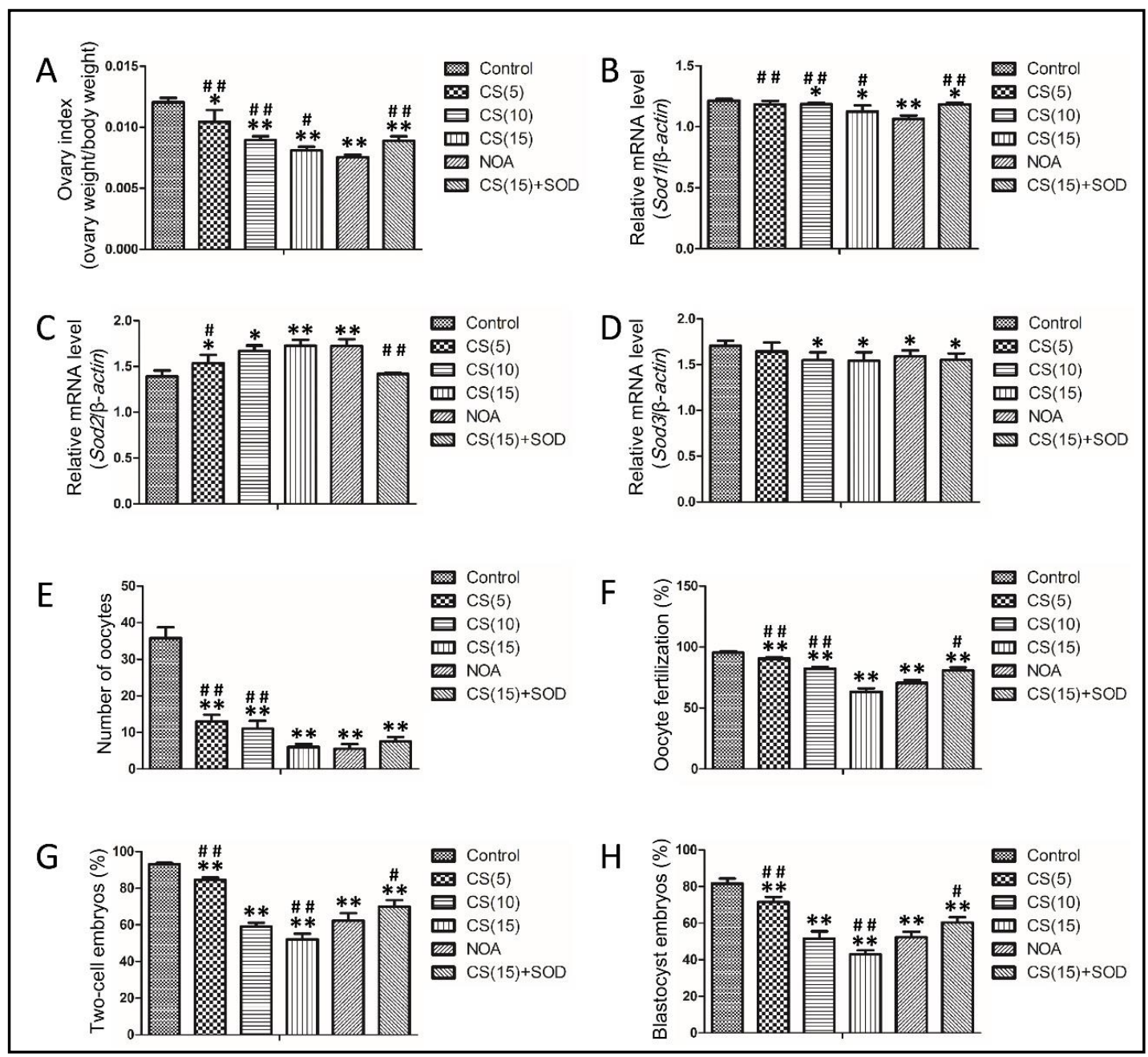

Fig. 7. Effect of an oxidation inhibitor on ovarian oxidative stress and oocyte quality after consecutive superovulation. (A) The ovary index was detected in all groups ( $n=8$ animals per group). The expression of the Sod1 (B), Sod2 (C) and Sod3 (D) mRNAs was assessed using Q-PCR ( $n=6$ animals per group), and number of oocytes, and rate of oocyte fertilization, and percentages of two-cell embryos and blastocyst embryos were also evaluated ( $\mathrm{n}=8$ samples per group). All data are presented as means \pm SD. Statistical significance: ${ }^{*} \mathrm{P}<0.05$ and ${ }^{* *} \mathrm{P}<0.01$ vs the control group, ${ }^{*} \mathrm{P}<0.05$ and ${ }^{\# *} \mathrm{P}<0.01$ vs the NOA group.

Effect of an oxidation inhibitor on ovarian oxidative stress and oocyte quality after consecutive superovulation

The ovary index was evaluated to further illuminate the role of oxidative stress in the ovary during consecutive superovulation. Consecutive superovulation significantly decreased the ovary index compared with the control group $(P<0.01)$. The SOD treatment significantly increased the ovary index compared with the NOA group $(P<0.01)$ (Fig. 7A).

Antioxidant enzymes, including SOD1, SOD2 and SOD3, play important roles in suppressing oxidative stress. Thus, we analyzed the mRNA expression of these enzymes during repeated ovulation (Fig. 7B-D). Sod1 and Sod3 mRNA levels decreased with repeated ovulation compared with the control group $(P<0.05$ or $P<0.01)$ (Fig. 7B and D). However, ovarian expression of the Sod3 mRNA was significantly increased during repeated ovulation $(P<0.01)$ (Fig. 7C). Interestingly, the SOD treatment significantly increased the Sod1 mRNA level and decreased the Sod2 mRNA level, but had no obvious effect on the Sod3 mRNA level. 


\section{Cellular Physiology Cell Physiol Biochem 2018;51:2341-2358 \begin{tabular}{c|c|c|c|} 
DOl: 10.1159/000495895 & (0) 2018 The Author(s). Published by S. Karger AG, Basel \\
www.karger.com/cpb
\end{tabular} \\ Nie et al.: Establishment of a Mouse Model of Premature Ovarian Failure}

SOD administration inhibited the oxidative stress events induced by repeated ovulation, and therefore, we tested its effect on the oocyte quality in vitro, as shown in Fig. 7E-H. Consecutive superovulation significantly decreased the number of oocytes, rate of oocyte fertilization, and percentages of two-cell embryos and blastocyst embryos compared with the control group $(P<0.01)$. The SOD treatment partially reversed these changes $(P<0.05$ or $P<0.01)$.

\section{Discussion}

POF can cause infertility, climacteric syndrome, osteoporosis, and senile dementia in females, which seriously affect women's health [37]. In this study, we examined the ovary aging effect of consecutive superovulation on mouse ovaries and generated an ovary aging mouse model by consecutive superovulation. In our study, both the primordial follicle pool and ovarian function were significantly decreased in the model mice, consistent with the characteristics of ovarian aging [3]; the model group displayed lower hormone levels and higher ROS and cell apoptosis levels than the control group, indicating that the model group displayed ovarian aging.

Ovarian function is primarily reflected in endocrine and reproductive functions. The E2, FSH, P and LH levels are classical criteria for POF [38]. This study showed that consecutive superovulation primarily affects the function of ovaries in female mice by decreasing E2 and $\mathrm{P}$ and increasing FSH and LH. Many reports have shown that repeated superovulation directly induces oxidative stress in vivo, attenuates FSH bioactivity and inhibits E2 production in granulosa cells $[3,28]$. These results demonstrated that consecutive superovulation may affect ovarian endocrine function, and the trend was consistent with that in NOA mice.

The basis of reproductive aging in women is ovarian aging [1]. The central hypothesis is that the number of primordial follicles and the quality of oocyte cells in the ovaries decrease gradually $[39,40]$. In this accelerated ovarian aging model, the number of primordial follicles was substantially decreased, whereas the number of atretic follicles was significantly increased. Conversely, the decreased numbers of primordial, primary and secondary follicles resulted in a decreased number of total follicles, consistent with the results of a previous report [3]. In addition to the decrease in the number of antral follicles, the AMH and INH B decline was increased by consecutive superovulation in our study. AMH, which is produced predominantly by preantral and small antral follicles, and INH B, which is secreted by granulosa cells of small growing follicles, are two well-established markers of ovarian reserve and very important early markers of ovarian aging [38, 41-43], as they reflect the size of the ovarian follicle pool [44]. Decreased expression of AMH and INH B has been detected long before normal menopause [45-47] and during the normal course of aging in mice [48]. Thus, consecutive superovulation successfully induced the mouse POF model in the present study.

A previous report revealed that ovarian aging is associated with oxidative stress [49]. The accumulation of oxidative stress exerts long-term effects on ovarian follicle depletion $[27,50]$. In addition, the cyclical production of ROS may cause cumulative damage to DNA that contributes to ovarian aging [51]. Repeated ovarian stimulation has been shown to induce oxidative damage and mitochondrial DNA mutations in ovaries, increase the incidence of oocyte spindle defects, and decrease the quality of oocytes [52-54]. In the present study, consecutive superovulation increased MDA, a lipid peroxidation index, while at the same time, it decreased SOD and GSH-Px, superoxide radical scavenger enzymes. According to the results of the immunohistochemical staining, consecutive superovulation also significantly increased the levels of 8-OhdG, 4-HNE and NTY; DHE staining showed that consecutive superovulation increased ROS levels in the mouse ovary, indicating that the ovary was in a high oxidative stress state following consecutive superovulation. The intracellular antioxidant system is involved in various oxidation-reduction reactions of organelles and is 
activated by a low concentration of ROS as a signal [55]. Elevated oxidative stress in cells is the leading cause of cellular aging [56-58] and ovarian aging [59].

Oxidative stress increases the vulnerability of the body and at the same time can enhance the toxic effects of the pathogenic factors and genetic mutations, leading to the occurrence and development of various diseases and granulosa cell apoptosis [60]. Granulosa cells play a key role in nurturing and supporting oocyte development [61]. Granulosa cells form the follicular microenvironment, which facilitates oocyte development, supplies energy, disposes of waste and participates in molecular signaling [62]. If the function of granulosa cells becomes impaired during aging, then oocyte growth and competence will also be compromised [63]. Ovarian stimulation was shown to impact granulosa cell apoptosis and biological aging of the ovary [64-66]. Ovarian granulosa cell apoptosis is an important marker of ovarian aging [39]. The results of TUNEL fluorescence staining showed that apoptotic granulosa cells increased in ovarian follicles in ovaries that underwent consecutive superovulation compared to those of the control group, suggesting that follicular degeneration is accelerated by consecutive superovulation.

Overproduction of ROS in oocytes and embryos not only leads to oxidative stress and follicular degeneration but also decreases the quality of eggs and influences early embryonic development [23, 67]. Excessive production of ROS in mural granulocytes and ovarian granulocytes also reduces fertilization and embryo quality [68]. In addition, ROS are also involved in early embryonic developmental arrest, such as the mouse 2-cell embryo developmental block, which is closely related to an increase in ROS levels [69]. Based on the results from our study, ROS accumulation during consecutive superovulation may be an important cause of decreased ovarian function and egg quality. SOD1 neutralizes superoxide anions in the cytoplasm of cells, and in this case, the oocyte is likely an abundant producer of ROS, as it is metabolically active during the acquisition of developmental competence [70]. Mammalian oocytes possess a large number of mitochondria, the organelle where SOD2 is preferentially localized [71]. SOD2 is one of the most important antioxidant enzymes in the body, and its expression levels are increased following oxidative stress [72, 73]. SOD3 acts in the extracellular matrix [74], a dynamically regulated and essential component of the developing COCs. In addition, oocytes, or COCs as a whole developmental unit, may stockpile the various SOD isoforms for the upcoming events in oocyte maturation, fertilization, and early embryonic development. These processes occur precisely when the oocyte is faced with increasing oxidative challenges, such as the proposed burst of ROS at ovulation [75] and the increase in oxygen tension within the oviduct $[76,77]$. Based on findings from the present study, the protective effect of SOD might partially rescue ovarian function by inhibiting ROS production. Exogenous SOD inhibits apoptosis in cultured rat follicles [78]. Conceivably, external factors may influence the oxidative stress status and in turn SOD expression in the follicle [79].

The regulatory mechanisms responsible for attenuating ROS levels and promoting apoptosis resistance in the ovary remain elusive. Consecutive superovulation significantly increased p16 expression in ovarian tissues and decreased SIRT1 and FOX01 levels. The p16 pathway is a signaling pathway that plays important roles in aging. The p16 protein is expressed at low levels in tissues from young animals, and its expression increases with aging $[80,81]$. The p16 protein is currently believed to be a marker of tissue and cell aging $[82,83]$. The mechanism by which p16 induces senescence is based on the role of $\mathrm{p} 16$ as a cell cycledependent kinase inhibitor that causes cell cycle arrest and subsequent senescence [80]. The expression of p16 is associated with oxidative stress in multiple cell lines [80, 81]. Thus, the increase in the level of the 16 protein induced by consecutive superovulation in this study indicated that high oxidative stress levels in ovaries might promote p16 expression, and consecutive superovulation up-regulates the expression of the senescence protein p16 and promotes ovarian aging via the p16 signaling pathway. SIRT1 is regarded as an antiaging or longevity protein [84]. SIRT1, which is primarily localized in cell nuclei, regulates gene transcription and DNA repair and has been linked to the onset of aging and agingassociated diseases [85]. Sirtuins suppress age-related dysfunction and increase longevity

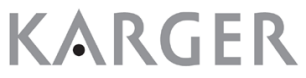




\section{Cellular Physiology Cell Physiol Biochem 2018;51:2341-2358

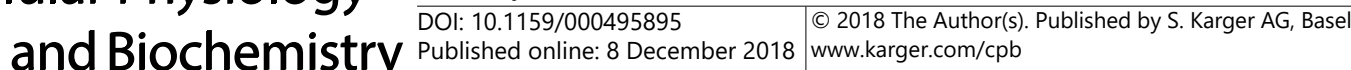 \\ Nie et al.: Establishment of a Mouse Model of Premature Ovarian Failure}

by increasing SIRT1 expression [86, 87]. FOX01 is deacetylated by SIRT1 to evoke cellular resistance to stress by promoting the expression of antioxidant enzymes that detoxify ROS or induce cell cycle arrest to allow time for DNA repair and other repair processes [88, 89]. In our study, Western blotting revealed that consecutive superovulation decreased the SIRT1 and FOX01 levels in a cycle number-dependent manner. Several lines of evidence support this result and indicate that SIRT1 plays a key role in the adaptive responses of cells to a variety of oxidative stressors $[88,90]$. The SIRT1/FOX01 pathway may be a crucial regulator of apoptosis and oxidative stress resistance, consistent with the findings of previous reports $[91,92]$.

\section{Conclusion}

Consecutive superovulation effectively induced oxidative stress, apoptosis and ovarian injury via multiple mechanisms, including the p16 and SIRT1/FOXO1 signaling pathways. Based on these results, the POF mouse model was established by more than 10 consecutive superovulation treatments, and inhibition of p16 and SIRT1/FOX01 signaling pathways might be a potential protective mechanism to reduce injury caused by ovary superovulation in human and animal assisted reproduction procedures.

\section{Acknowledgements}

This work was supported by the National Natural Science Foundation of China (81774357, 81403426, 81674012) and the Science and Technology Development Key Projects Fund of Nanjing Medical University (2016NJMUZD020).

\section{Disclosure Statement}

The authors declare that they have no competing interests.

\section{References}

1 Bandyopadhyay S, Chakrabarti J, Banerjee S, Pal AK, Goswami SK, Chakravarty BN, Kabir SN: Galactose toxicity in the rat as a model for premature ovarian failure: An experimental approach readdressed. Human reproduction 2003;18:2031-2038.

-2 Liu G Hale GE, Hughes CL: Galactose metabolism and ovarian toxicity. Reprod Toxicol Sci 2000;14:377-384.

-3 Zhang J, Fang L, Shi L, Lai Z, Lu Z, Xiong J, Wu M, Luo A, Wang S: Protective effects and mechanisms investigation of kuntai capsule on the ovarian function of a novel model with accelerated aging ovaries. Journal of Ethnopharmacology 2017;195:173-181.

4 Balla A, Danilovich N, Yang Y, Sairam M: Dynamics of ovarian development in the forko immature mouse: Structural and functional implications for ovarian reserve. Biol Reprod 2003;69:1281-1293.

-5 Danilovich N, Babu PS, Xing W, Gerdes M, Krishnamurthy H, Sairam MR: Estrogen deficiency, obesity, and skeletal abnormalities in follicle-stimulating hormone receptor knockout (forko) female mice. Endocrinology 2000;141:4295-4308.

-6 Abbott BD, Schmid JE, Pitt JA, Buckalew AR, Wood CR, Held GA, Diliberto JJ: Adverse reproductive outcomes in the transgenic ah receptor-deficient mouse. Toxicol Appl Pharmacol 1999;155:62-70.

7 Benedict JC, Lin TM, Loeffler IK, Peterson RE, Flaws JA: Physiological role of the aryl hydrocarbon receptor in mouse ovary development. Toxicol Sci 2000;56:382-388.

8 Hoyer PB, Devine PJ, Hu X, Thompson KE, Sipes IG: Ovarian toxicity of 4-vinylcyclohexene diepoxide: A mechanistic model. Toxicol Pathol 2001;29:91-99. 


\section{Cellular Physiology Cell Physiol Biochem 2018;51:2341-2358

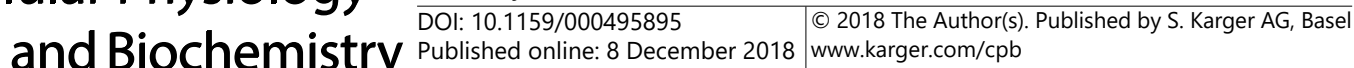

99 Mayer LP, Devine PJ, Dyer CA, Hoyer PB: The follicle-deplete mouse ovary produces androgen. Biol Reprod 2004;71:130-138.

10 Song X, Bao M, Li D, Li YM: Advanced glycation in d-galactose-induced mouse aging model. Mech Ageing Dev 1999;108:239-251.

11 Semba RD, Nicklett EJ, Ferrucci L: Does accumulation of advanced end products contribute to the aging phenotype? J Gerontol A Biol Sci Med Sci 2010;65:963-975.

$\checkmark 12$ Yan Z, Dai Y, Fu H, Zheng Y, Bao D, Yin Y, Chen Q Nie X, Hao Q, Hou D, Cui Y: Curcumin exerts a protective effect against premature ovarian failure in mice. Journal of Molecular Endocrinology 2018;60:261-271.

13 Danilovich N, Ram Sairam M: Recent female mouse models displaying advanced reproductive aging. Exp Gerontol 2006;41:117-122.

14 Armstrong DT: Prostaglandins and follicular functions. J Reprod Fertil 1981;62:283-291.

15 Kitai H, Kobayashi Y, Santulli R, Wright KH, Wallach EE: The relationship between prostaglandins and histamine in the ovulatory process as determined with the in vitro perfused rabbit ovary. Fertil Steril 1985; 43:646-651.

16 Yoshimura Y, Espey L, Hosoi Y, Adachi T, Atlas SJ, Ghodgaonkar RB, Dubin NH, Wallach EE: The effects of bradykinin on ovulation and prostaglandin production by the perfused rabbit ovary. Endocrinology 1988;122:2540-2546.

17 Sato EF, Kobuchi H, Edashige K, Takahashi M, Yoshioka T, Utsumi K, Inoue M: Dynamic aspects of ovarian superoxide dismutase isozymes during the ovulatory process in the rat. FEBS Lett 1992;303:121-125.

18 Espey LL, Stein VI, Dumitrescu J: Survey of antiinflammatory agents and related drugs as inhibitors of ovulation in the rabbit. Fertil Steril 1982;38:238-247.

19 Laloraya M, Pradeep KG, Laloraya MM: Changes in the levels of superoxide anion radical and superoxide dismutase during the estrous cycle of rattus norvegicus and induction of superoxide dismutase in rat ovary by lutropin. Biochem Biophys Res Commun 1988;157:146-153.

-20 Wang Z, Tamura K, Yoshie M, Tamura H, Imakawa K, Kogo H: Prostaglandin f2alpha-induced functional regression of the corpus luteum and apoptosis in rodents. J Pharmacol Sci 2003;92:19-27.

-21 Minegishi K, Tanaka M, Nishimura O, Tanigaki S, Miyakoshi K, Ishimoto H, Yoshimura Y: Reactive oxygen species mediate leukocyte-endothelium interactions in prostaglandin f2alpha-induced luteolysis in rats. Am J Physiol Endocrinol Metab 2002;283:1308-1315.

22 Schallreuter KU, Moore J, Wood JM, Beazley WD, Gaze DC, Tobin DJ, Marshall HS, Panske A, Panzig E, Hibberts NA: In vivo and in vitro evidence for hydrogen peroxide (H2O2) accumulation in the epidermis of patients with vitiligo and its successful removal by a uvb-activated pseudocatalase. J Invest Dermatol Symp Proc 1999;4:91-96.

-23 Yang HW, Hwang KJ, Kwon HC, Kim HS, Choi KW, Oh KS: Detection of reactive oxygen species (ros) and apoptosis in human fragmented embryos. Hum Reprod 1998;13:998-1002.

24 Van Blerkom J1, Antczak M, Schrader R: The developmental potential of the human oocyte is related to the dissolved oxygen content of follicular fluid: Association with vascular endothelial growth factor levels and perifollicular blood flow characteristics. Hum Reprod 1997;12:1047-1055.

-25 Liu L, Keefe DL: Cytoplasm mediates both development and oxidation-induced apoptotic cell death in mouse zygotes. Biol Reprod 2000;62:1828-1834.

-26 Eichenlaub-Ritter U, Boll I: Nocodazole sensitivity, age-related aneuploidy, and alterations in the cell cycle during maturation of mouse oocytes. Cytogenet Cell Genet 1989;52:170-176.

-27 Dong G, Guo Y, Cao H, Zhou T, Zhou Z, Sha J, Guo X, Zhu H: Long-term effects of repeated superovulation on ovarian structure and function in rhesus monkeys. Fertil Steril 2014;102:1452-1457.

28 Miyamoto K, Sato EF, Kasahara E, Jikumaru M, Hiramoto K, Tabata H, Katsuragi M, Odo S, Utsumi K, Inoue M: Effect of oxidative stress during repeated ovulation on the structure and functions of the ovary, oocytes, and their mitochondria. Free radical biology \& medicine 2010;49:674-681.

29 Tilly JL: Ovarian follicle counts--not as simple as 1, 2, 3. Reprod Biol Endocrinol 2003;1:11.

-30 Bernal AB, Vickers MH, Hampton MB, Poynton RA, Sloboda DM: Maternal undernutrition significantly impacts ovarian follicle number and increases ovarian oxidative stress in adult rat offspring. PLoS One 2010;5:e15558.

-31 Wang XN, Roy SK, Greenwald GS: In vitro DNA synthesis by isolated preantral to preovulatory follicles from the cyclic mouse. Biology of reproduction 1991;44:857-863. 


\section{Cellular Physiology Cell Physiol Biochem 2018;51:2341-2358 \begin{tabular}{ll|l} 
and Biochemistry Published online: 8 December 2018 & $\begin{array}{l}\odot 2018 \text { The Author(s). Published by S. Karger AG, Basel } \\
\text { www.karger.com/cpb }\end{array}$ \\
\hline
\end{tabular}

-32 Borgeest C, Symonds D, Mayer LP, Hoyer PB, Flaws JA.: Methoxychlor may cause ovarian follicular atresia and proliferation of the ovarian epithelium in the mouse. Toxicol Sci 2002;68:473-478.

-33 Zhao H, Kalivendi S, Zhang H, Joseph J, Nithipatikom K, Vásquez-Vivar J, Kalyanaraman B: Superoxide reacts with hydroethidine but forms a fluorescent product that is distinctly different from ethidium: potential implications in intracellular fluorescence detection of superoxide. Free Radical Biol Med 2002;33:13591368.

-34 Vásquez-Vivar J, Hogg N, Pritchard KA Jr, Martasek P, Kalyanaraman B: Superoxide anion formation from lucigenin: An electron spin resonance spintrapping study. FEBS Lett 1997;403:127-130.

-35 Behbahanian A, Eimani H, Zeinali B, Rezazadeh Valojerdi M, Eftekhari Yazdi P, Shahverdi A, Gourabi H, Golkar-Narenji A: In vitro maturation, fertilization and embryo culture of oocytes obtained from vitrified auto-transplanted mouse ovary. Int J Fertil Steril 2013;6:278-285.

-36 Hirshfield AN, Midgley AR Jr: Morphometric analysis of follicular development in the rat. . Biology of reproduction 1978;19:597-605.

37 Fridovich-Keil JL, Gubbels CS, Spencer JB, Sanders RD, Land JA, Rubio-Gozalbo E: Ovarian function in girls and woman with galt-deficiency galactosemia. J Inherit Metab Dis 2011;34:357-366.

38 Steiner AZ: Biomarkers of ovarian reserve as predictors of reproductive potential. Semin Reprod Med 2013;31:437-442.

39 Tufan E, Elter K, Durmusoglu F: Assessment of reproductive ageing patterns by hormonal and ultrasonographic ovarian reserve tests. Hum Rep Rod 2004;19:2484-2489.

40 Coxworth JE, Hawkes K: Ovarian follicle loss in humans and mice: Lessons from statistical model comparison. Hum Reprod 2010;25:1796-1805.

41 Tolikas A, Tsakos E, Gerou S, Prapas Y, Loufopoulos A: Anti-Mullerian Hormone (AMH) levels in serum and follicular fluid as predictors of ovarian response in stimulated (IVF and ICSI) cycles. Hum Fertil (Camb) 2011;14:246-253.

-42 Visser JA, Schipper I, Laven JS, Themmen AP: Anti-müllerian hormone: An ovarian reserve marker in primary ovarian insufficiency. Nat Rev Endocrinol 2012;8:331-341.

43 Sowers M, McConnell D, Gast K, Zheng H, Nan B, McCarthy JD, Randolph JF: Anti-mullerian hormone and inhibin b variability during normal menstrual cycles. Fertil Steril 2010;94:1482-1486.

44 Feyereisen E, Méndez Lozano DH, Taieb J, Hesters L, Frydman R, Fanchin R: Anti-müllerian hormone: Clinical insights into a promising biomarker of ovarian follicular status. Reproductive Biomedicine;12:695-703.

45 Freeman EW, Sammel MD, Lin H, Gracia CR.: Anti-mullerian hormone as a predictor of time to menopause in late reproductive age women. J Clin Endocrinol Metab 2012;97:1673-1680.

46 Sanders RD, Spencer JB, Epstein MP, Pollak SV, Vardhana PA, Lustbader JW, Fridovich-Keil JL: Biomarkers of ovarian function in girls and women with classic galactosemia. Fertil Steril 2009;92:344-351.

47 Seifer DB, Baker VL, Leader B: Age-specific serum anti-müllerian hormone values for 17, 120 women presenting to fertility centers within the united states. Fertility and Sterility 2011;95:747-750.

48 Kevenaar ME, Meerasahib MF, Kramer P, van de Lang-Born BM, de Jong FH, Groome NP, Themmen AP, Visser JA: Serum anti-mullerian hormone levels reflect the size of the primordial follicle pool in mice. Endocrinology 2006;147:3228-3234.

-49 Broekmans FJ, Soules MR, Fauser BC.: Ovarian aging: Mechanisms and clinical consequences. Endocr Rev 2009;30:465-493.

50 Chao HT, Lee SY, Lee HM, Liao TL, Wei YH, Kao SH: Repeated ovarian stimulations induce oxidative damage and mitochondrial DNA mutations in mouse ovaries. Ann NY Acad Sci 2005;1042:148-156.

51 Jeelani R, Khan SN, Shaeib F, Kohan-Ghadr HR, Aldhaheri SR, Najafi T, Thakur M, Morris R, Abu-Soud HM: Cyclophosphamide and acrolein induced oxidative stress leading to deterioration of metaphase ii mouse oocyte quality. Free Radic Biol Med 2017;110:11-18.

52 Van der Auwera I, D’Hooghe T: Superovulation of female mice delays embryonic and fetal development. Hum Reprod Update 2001;16:1237-1243.

-53 Chao HT, Lee SY, Lee HM, Liao TL, Wei YH, Kao SH: Repeated ovarian stimulations induce oxidative damage and mitochondrial DNA mutations in mouse ovaries. Ann N Y Acad Sci 2005;1042:148-156.

54 Van Blerkom J, Davis P: Differential effects of repeated ovarian stimulation on cytoplasmic and spindle organization in metaphase ii mouse oocytes matured in vivo and in vitro. Human reproduction 2001;16:757-764. 


\section{Cellular Physiology Cell Physiol Biochem 2018;51:2341-2358 \begin{tabular}{l|l|l} 
and Biochemistry & DOl: 10.1159/000495895 & $\begin{array}{l}\text { C) } 2018 \text { The Author(s). Published by S. Karger AG, Basel } \\
\text { www.karger.com/cpb }\end{array}$
\end{tabular} \\ Nie et al.: Establishment of a Mouse Model of Premature Ovarian Failure}

55 Jones DP: Radical-free biology of oxidative stress. Am J Physiol Cell Physiol 2008;295:849-868.

56 Marchi S, Giorgi C, Suski JM, Agnoletto C, Bononi A, Bonora M, De Marchi E, Missiroli S, Patergnani S, Poletti F, Rimessi A, Duszynski J, Wieckowski MR, Pinton P: Mitochondria-ros crosstalk in the control of cell death and aging. J Signal Transduct 2012;2012:329635.

57 Brink TC, Demetrius L, Lehrach H, Adjaye J: Age-related transcriptional changes in gene expression in different organs of mice support the metabolic stability theory of aging. Biogerontology 2009;10:549-564.

-58 Cui H, Kong Y, Zhang H: Oxidative stress, mitochondrial dysfunction, and aging. J Signal Transduct 2012;2012:646354.

59 Vitale G, Salvioli S, Franceschi C: Oxidative stress and the ageing endocrine system. Nat Rev Endocrinol 2013;9:28-40.

60 Matés JM, Segura JA, Alonso FJ, Márquez J: Oxidative stress in apoptosis and cancer: an update. Arch Toxicol 2012;86:1649-1665.

61 Ben-Meir A, Yahalomi S, Moshe B, Shufaro Y, Reubinoff B, Saada A: Coenzyme Q-dependent mitochondrial respiratory chain activity in granulosa cells is reduced with aging. Fertil Steril 2015;104:724-727.

62 Tatone C, Amicarelli F: The aging ovary-the poor granulosa cells. Fertil Steril 2013;99:12-17.

63 Wu YG, Barad DH, Kushnir VA, Lazzaroni E, Wang Q, Albertini DF, Gleicher N: Aging-related premature luteinization of granulosa cells is avoided by early oocyte retrieval. J Endocrinol 2015;226:167-180.

64 Combelles CM, Albertini DF: Assessment of oocyte quality following repeated gonadotropin stimulation in the mouse. Biol Reprod 2003;68:812-821.

65 Benadiva C, Engmann L: Luteal phase support after gonadotropin-releasing hormone agonist triggering: does it still matter? Fertil Steril 2018;18:30074-30078.

-66 Tarín JJ, Pérez-Albalá S, Cano A: Cellular and morphological traits of ooytes retrieved from aging mice after exogenous ovarian stimulation. Biol Reprod 2001;65:141-150.

-67 Goud AP, Goud PT, Diamond MP, Gonik B, Abu-Soud HM: Reactive oxygen species and oocyte aging: role of superoxide, hydrogen peroxide, and hypochlorous acid. Free Radical Biology and Medicine 2008;44:12951304.

68 Seino T, Saito H, Kaneko T, Takahashi T, Kawachiya S, Kurachi H: Eight-hydroxy-2'-deoxyguanosine in granulosa cells is correlated with the quality of oocytes and embryos in all in vitro fertilization-embryo transfer program. Fertil Steril 2002;77:1184-1190.

69 Noda Y, Matsumoto H, Umaoka Y, Tatsumi K, Kishi J, Mori T: Involvement of superoxide radicals in the mouse two-cell block. Molecular reproduction and development 1991;28:356-360.

70 Sutton ML, Gilchrist RB, Thompson JG: Effects of in-vivo and in-vitro environments on the metabolism of the cumulus-oocyte complex and its influence on oocyte developmental capacity. Hum Reprod Update 2003;9:35-48.

71 Johnson F, Giulivi C: Superoxide dismutases and their impact upon human health. Mol Aspects Med 2005;26:340-352.

72 Scandalios JG: Oxidative stress: Molecular perception and transduction of signals triggering antioxidant gene defenses. Braz J Med Biol Res 2005;38:995-1014.

73 Zhang JQ, Shen M, Zhu CC, Yu FX, Liu ZQ, Ally N, Sun SC, Li K, Liu HL: 3-nitropropionic acid induces ovarian oxidative stress and impairs follicle in mouse. PloS one 2014;9:e86589.

-74 Nozik-Grayck E SH, Piantadosi CA. : Extracellular superoxide dismutase. Int J Biochem Cell Biol 2005;37:2466-2471.

75 Fujii J, Iuchi Y, Okada F: Fundamental roles of reactive oxygen species and protective mechanisms in the female reproductive system. Reprod Biol Endocrinol 2005;3:43.

76 Fischer B, Künzel W, Kleinstein J, Gips H: Oxygen tension in follicular fluid falls with follicle maturation. Eur J Obstet Gynecol Reprod Biol 1992;43:39-43.

77 Fischer B, Bavister BD: Oxygen tension in the oviduct and uterus of rhesus monkeys, hamsters and rabbits. J Reprod Fertil 1993;99:673-679.

78 Tilly JL, Tilly KI: Inhibitors of oxidative stress mimic the ability of follicle-stimulating hormone to suppress apoptosis in cultured rat ovarian follicles. Endocrinology 1995;136:242-252.

79 Valdez KE, Cuneo SP, Turzillo AM: Regulation of apoptosis in the atresia of dominant bovine follicles of the first follicular wave following ovulation. Reproduction 2005;130:71-81.

80 Attema JL, Pronk CJ, Norddahl GL, Nygren JM, Bryder D: Hematopoietic stem cell ageing is uncoupled from p16 ink4a-mediated senescence. Oncogene 2009;28:2238-2243. 


\section{Cellular Physiology Cell Physiol Biochem 2018;51:2341-2358 \begin{tabular}{ll|l} 
and Biochemistry & Dublished online: 8 December 2018 & $\begin{array}{l}\text { O 2018 The Author(s). Published by S. Karger AG, Basel } \\
\text { www.karger.com/cpb }\end{array}$ \\
\cline { 2 - 3 }
\end{tabular}

81 Kim H, You S, Farris J, Kong BW, Christman SA, Foster LK, Foster DN: Expression profiles of p53-, p16(ink4a)-, and telomere-regulating genes in replicative senescent primary human, mouse, and chicken fibroblast cells. Experimental cell research 2002;272:199-208.

-82 Krishnamurthy J, Torrice C, Ramsey MR, Kovalev GI, Al-Regaiey K, Su L, Sharpless NE: Ink4a/arf expression is a biomarker of aging. J Clin Invest 2004;114:1299-1307.

-83 Vasto S, Scapagnini G, Bulati M, Candore G, Castiglia L: Biomarkes of aging. Front Biosci (Schol Ed) 2010;2:392-402.

84 Morris BJ: Seven sirtuins for seven deadly diseases of aging. Free radical biology medicine 2013;56:133171.

-85 Satoh A, Brace CS, Rensing N, Cliften P, Wozniak DF, Herzog ED, Yamada KA, Imai S.: Sirt1 extends life span and delays aging in mice through the regulation of Nk2 homeobox 1 in the DMH and LH. Cell Metab 2013;18:416-430.

86 Chang HC, Guarente L: Sirt1 mediates central circadian control in the SCN by a mechanism that decays with aging. Cell 2013;153:1448-1460.

87 Rimmelé P, Bigarella CL, Liang R, Izac B, Dieguez-Gonzalez R, Barbet G, Donovan M, Brugnara C, Blander JM, Sinclair DA, Ghaffari S: Aging-like phenotype and defective lineage specification in sirt1-deleted hematopoietic stem and progenitor cells. Stem Cell Reports 2014;3:44-59.

-88 Zhang XS, Wu Q, Wu LY, Ye ZN, Jiang TW, Li W, Zhuang Z, Zhou ML, Zhang X, Hang CH: Sirtuin 1 activation protects against early brain injury after experimental subarachnoid hemorrhage in rats. Cell Death Dis 2016; $7: \mathrm{e} 2416$.

89 Gu X, Han D, Chen W, Zhang L, Lin Q, Gao J, Fanning S, Han B: Sirt1-mediated foxos pathways protect against apoptosis by promoting autophagy in osteoblast-like mc3t3-e1 cells exposed to sodium fluoride. Oncotarget 2016; 7:65218-65230.

90 Ahn J, Lee H, Jung CH, Jeon TI, Ha TY: MicroRNA-146b promotes adipogenesis by suppressing the SIRT1FOX01 cascade. EMBO Mol Med 2013;5:1602-1612.

-91 Liang F, Kume S, Koya D: Sirt1 and insulin resistance. Nat Rev Endocrinol 2009;5:367-373.

92 Ding C, Zou Q, Wang F, Wu H, Wang W, Li H, Huang B: HGF and bFGF secretion by human adipose-derived stem cells improves ovarian function during natural aging via activation of the SIRT1/FOXO1 signaling pathway. Cell Physiol Biochem 2018;45:1316-1332. 